\title{
How Financial Leverage Differs Between Conventional and Islamic Banks: A Dynamic Model Perspective of Banking Sector in Pakistan
}

\author{
Naila Hameed ${ }^{1 *}$, Muhammad Naveed ${ }^{2}$, Shahzad Ahmad Khan ${ }^{3}$ \\ ${ }^{1}$ HEC PhD scholar at FMS, Riphah International University, Islamabad, Pakistan \\ ${ }^{2}$ Associate Professor, the Faculty of Management Sciences, Shaheed Zulfiqar Ali Bhuto University, \\ Islamabad, Pakistan \\ ${ }^{3}$ Assistant Professor, the Faculty of Management Sciences (FMS), Riphah International University, \\ Islamabad, Pakistan
}

\section{Keywords \\ Financial Leverage \\ IBs, \\ CBs, \\ Speed of Adjustment, \\ System GMM}

Received: 21-Jan-19

Accepted: 29-Apr-19

\begin{abstract}
This study addresses the dynamic aspects of financial leverage in banking sector in Pakistan. Using theoretical and empirical insights, it aims to highlight the differences in leverage between Conventional Banks (CBs) and Islamic Banks (IBs). The study works with dynamic model (System GMM) to explore the existence of target leverage and variation in the speed of adjustment across CBs and IBs. In accordance with dynamic framework, the study observes the dynamics of the association between the exogenous variables and financial leverage. Study is deviation from textbook theory of bank capital and has embraced with sophisticated model to illustrate that the banks optimize and adjust their capital structure with environmental shocks and financial variations. Looking into very dynamic nature of environment, the study reports that in CBs the economic shocks and financial variations adjustment time tends to maintain adjustments in 1.88 years while IBs tend to maintain it in 0.82 year. Moreover, variations are found about the impacts of economic growth, inflation and sectoral nature in both Islamic and conventional banking. It will help policy makers in financial markets as well as mangers of both IBs and CBs by providing insights about dynamics of leverage. Systemic financial reforms after the global financial crisis and financial digital landscape are advised for banking industry that stress the development of hedging doctrines for deposits and deposit income. Therefore, there is a strong need to revisit hedging doctrine and risk management models for the banking sector in Pakistan that is relatively sluggish.
\end{abstract}

KAUJIE Classification: Q9, L4

JEL Classification: C5, G21, E51, G3

(C) 2019 JIBM. All rights reserved.

\footnotetext{
*Corresponding author: Naila Hameed

†Email: naila_kpr@yahoo.com
} 


\section{INTRODUCTION}

From the inception of industrial revolution the trend of using debt got substantial popularity in almost every industry hence starting the debate of pros and cons associated with utilization of debt. However, capital structure literature is full of applicability of capital structure theories for non-financial sector and mainly focuses on manufacturing industry but lacks insights on financial institutions. Moreover, the presence of capital or equity in financial firms is not as simple as in non-financial firms due to the differences in composition of assets and liabilities of financial firms. Literature related to capital structure of financial sector claims that regulatiory capital requirement is the prime determinant of capital structure in financial sector. The main reason of scarce work in this domain is that theories dealing with capital structure mostly are explained with the sample of Non-Financial sector. This exclusion of financial sector claims that capital structure of financial sectors is primarily determined by capital requirement regulations. The leverage of banks is highly composed of deposit liabilities making it inappropriate to compare with non-financial sector characterized with the absence of deposit liabilities. Additionally, banks and financial institutions are characterized as highly levered firms as compared to non-financial firms. These differences in leverage validate the prominence of exploring financial sector leverage systematically as of non-financial sector.

Further, empirical studies on non-financial firms confirm presence of dynamism and significance of sector in leverage (Lemma \& Negash, 2014; MacKay \& Phillips, 2005). Whereas, for financial sector (as best of researchers knowledge) there is no study that incorporates nature of sector for leverage. Also, inclusion of IBs sample for this study is relevant because (as best of researcher's knowledge) Islamic finance literature is silent on this topic. As indicated by Narayan and Phan (2019), the most important challenge which Islamic finance literature faces is lack of research on corporate finance topics like capital structure determinants and dynamics of leverage in IBs. This study highlights dynamics of leverage with the pertinence of sector level factors which have been ignored in case of financial sector. We have extended our investigation including dynamic analysis and speed of adjustment towards target capital structure. We have also conducted the comparative analysis keeping in view the theoretical differences between IBs and CBs.

Therefore, prime objective of the paper is to assess, whether behavior of banks leverage holds corporate finance theories of capital structure, and leverage of banks is dynamic in nature (as in case of non-financial firm) or not. It also investigates the similarities and differences in determinants of leverage across IBs and CBs. To create the context of this study we started with providing background information emphasising on theoretical differences in leverage across financial and non-financial firms resulting in arguments regarding prominence of studying banks leverage. By using several contentious opinions and existing literature, we justified the pertinence of comparative analysis for financial leverage across IBs and CBs. 


\section{THEORETICAL DEVELOPMENT}

First, we address the assertion that capital regulations are sufficient to determine capital structure decision of banks while other (non-financial firm specific) determinants of corporate literature have no or negligible explanatory powers to explain capital structure of banks. Instead of having similar standard capital regulation requirement for all banks, the literature reports a wide range of discrimination of leverage within banks. Berger, Hasan, and Zhou (2009) report that the banks possess much higher level of equity than the standard regulations. It is a normal trend that banks retain additional capital over and above the regulatory capital which is known as discretionary or buffer capital. This is justified as buffer View. The banks retain additional capital to avoid the chances of falling below the regulated capital and to evade issuing cost of equity incured in raising capital at short notice. So, by this definition the level of buffer a bank holds must be related to cost of equity and probability of hitting threshold capital.

But empirical evidences of studies challenge this buffer view assertion and report determinants of banks capital structure other than just capital regulation. Gropp and Heider (2010) analyze sample of US and EU largest banks and conclude that capital regulation and buffers are not first order determinants. However, the other factors significant for non-financial firms like size, profitability, growth, tangibility, are equally important with regard to the banks leverage. Theoretical contributions in banks literature are also contradictory to regulation based capital and are consistent with stable capital view. In this regard, there are two competing approaches: managerial preference based approach (Bertrand \& Schoar, 2003; Frank \& Goyal, 2007) and asset liability interaction approach (Allen, Fulghieri, \& Mehran, 2011; Diamond \& Rajan, 2000). According to the managerial preference approach. risk averse managers will be less aggressive in their approach and would prefer low leverage in banks' capital structure. While according to the asset liability interaction approach, less volatile asset structure will result into stable capital structure.

Under the umbrella of manager preference view, the capital structure of financial and non-financial firms should be determined on same parameters, while according to asset based view bank assets are different from that of non-financial firms; therefore banks' capital structure should be studied separately with specific factors. In contrast to standard pure regulatory view on bank capital structure (Regulation and Buffer view) market view on bank capital structure advocates that market forces and determinants explain bank capital structure. So, conferring to market view regulatory requirement and buffer can't be first order determinants of bank capital structure as evident from Gropp and Heider (2010) and Berg and Gider (2017). Capital structure resulted by the debt holders, depositors and by shareholders expectations build pressure as a result of which the banks adjust capital leverage. Characteristics of bank capital are supposed to be different from non-financial firm capital as debt is highly attractive and advantageous for banks than that of equity. Comparative to equity, informational insensitivity of debt attributed with safety, ease of evaluation and immediacy justifies presence of high debt in banks. Whereas, the presence of equity capital encourages banks to behave prudently by retaining through taking excessive risk. Instead of being highly leveraged institutions banks enjoy safety net like bail-out guarantees and 
deposit insurance which aggravates risk-taking in banks. Risk-taking fetches high returns for managers and shareholders; however, expected losses are primarily shifted to debtholders and taxpayers (Košak, Lončarski, \& Marinč, 2015). Consequently, a sufficient level of capital is only the remedy to ensure prudent lending by banks (Goodhart, Hartmann, Llewellyn, Rojas-Suarez, \& Weisbrod, 2013). Here, comes the role of regulatory requirement of bank capital which require banks to maintain an optimal capital to avoid risk and losses.

The theoretical exploration of Basel Accords in debate of banks leverage and optimal level of capital are inevitable. Prominent history of Basel Accord started in 1988 with Basel I, based on credit-risk rationale that propagated importance of adequate capital to reduce systemic risk. As indicated by Engelen (2005), Basel I was accepted globally by over 100 states and countries. In Basel II, 2004 banks were required to maintain capital primarily determined by bank's risk as assessed by them. The presence of asymmetric information between bank and regulator has advantage for the bank to belittle its risk. The imposition of Basel III restricts such behavior by simply adding leverage ratio in deciding minimum required capital. Resulting from economic crisis, Cannata and Quagliariello (2009) argue that many banks had insufficient capability to absorb loan defaults and this situation increased riskiness of bank's assets with a question on its landing ability. The concept of capital adequacy is primarily linked to prevention of bank failure. The basic purpose of the Bank of International Settlements (BIS) was to ensure protection of depositors as well as banks (during adversity) by imposing Capital Adequacy Requirement (CAR).

In Pakistan, the State Bank of Pakistan (SBP) plays supervisory and regulatory role for overall banking sector. Pakistan is a country which accommodates dual banking system (IBs parallel with CBs). In 2005, the SBP announced a schedule for implementation of the Basel Accord under BCBS (the Basel Committee on Bank Supervision) guidance. However, in Pakistan implementation of Basel Accord is late and lags behind other countries (Masood \& Fry, 2012).

\section{IBs vs CBs}

Bank leverage is composed of deposits and non-deposits and deposits are considered the main source of banks' funding which are converted into loans to generate profits. Deposits are inherited with risk of withdrawal linked with competitive performance of banks. Theoretically in case of IBs depositors have religious affiliations therefore risk of withdrawal is negligible as compare to CBs. IBs offer Sharī'ah compliance products and their activities are also different from the CBs. IBs retain two types of depositors: first who place their money on custody/trust basis with the right to withdraw any time and expect no, or little return $^{1}$. Second type of depositors are classified as investment depositors who wish to earn profit on their deposits based on mudārabah principles. It places liability to share the loss, if any, on the depositors. CBs, on the other hand, set depositors free from any liability of loss and guarantee safety of depositor's principal and the agreed return. Comparbly, IBs are not

\footnotetext{
${ }^{1}$ In recent years, IBs in Pakistan have started remunerative Current Accounts, offered to business community on the basis of mudārabah (State Bank of Pakistan (SBP), 2019). A little weightage is given to such deposits and only small return is allocated to them that commensurates the benefits/facilities given to such business account holders.
} 
obliged to promise a pre-determined rate, as interest rate guaranteed by CBs. Chemistry of Islamic and CB leverage can also be differentiated on the basis of afore mention arguments. Theoretically, minimum CAR seems to be irrelevant for IBs as profit-loss sharing nature of contract in IBs reduce risk on investment (Pellegrina, 2012). But presence of information asymmetries and risks related to IBs products, invites empirical research on pertinence of capital in Islamic Banking as compared to CBs (Karim, Hassan, Hassan, \& Mohamad, 2014).

Due to the difference in ideology and operational nature of CBs and IBs, a number of comparative studies have been performed on efficiency and profitability of these banks (Abedifar, Molyneux, \& Tarazi, 2013; Jaffar \& Manavri, 2011; Rashid, Khaleequzzaman, \& Jabeen, 2015). Because of the specific features, IBs normally have higher minimum capital requirements than that of $\mathrm{CBs}$, and because of asset based financing, they have to pay higher tax as well as registration cost (Salman \& Nawaz, 2018). Structural and functional differences lead to changes in financial characteristics of IBs.

Alkhazaleh and Almsafir (2015) tried to explain the impact of asymmetric information on IBs capital structure from the perspective of tangibility, dividend and growth, but the study lacked clarity on nature of capital structure. Hence, comprehensive studies on difference in leverage between IBs and CBs are scarce, and so far no study explains the dynamic nature of leverage and speed of adjustment towards targeted capital structure across IBs and CBs.

\section{Bank Leverage and Environmental Outlook}

Literature addressing capital structure of financial sector is scarce owing to capital regulations view; claiming that capital regulation requirement is the prime determinant of capital structure in financial sector. Most of the studies on capital structure consider non-financial firms' data and preferably manufacturing firms (Rashid, 2016), while financial sector in this regard is relatively ignored. However, some empirical evidences report significant departure from this view and support market view of capital structure; claiming that firm specific and market based factors also have explanatory power to determine capital structure of financial institutions (Gropp \& heider, 2010). Berg and Gider (2017) in their study "What explains the differences in leverage between banks and nonbanks" elaborated the differences between banks and nonbanks financial leverage. They explored common explanatory factors of leverage for US banks like size, profitability, tangibility and dividend, etc. Addition to borrowed factors from Berg and Gider (2017), this study also combined with other theoretically relevant factors. Firm level factors include size, profitability, tangibility, growth, Non-Debt Tax Shield (NDTS) and dividend.

Theory argues that large banks are well diversified in terms of borrowing and lending through capturing diversified regions and markets; hence their idiosyncratic risk is comparatively less, requiring less precautionary capital to maintain (Flannery \& Rangan, 2008). Moreover, larger banks usually face lower cost and coerces to raise their capital as compared to smaller banks Similarly, while talking about financial firms, tax changes are being used in banks studies as an explanatory as well as control variable (Berg \& Gider, 2017; Gropp $\&$ Heider, 2010). The scope of NDTS is broadly captured through depreciation, tax credits, research and development, staff training and Corporate Social Responsibility (CSR). Liter- 
ature on capital structure speaks about relationship between NDTS and proportion of debt and equity in non-financial sector. Hence, it becomes important to explore this dimension with the perspective of financial sector and whether NDTS has some explanatory power for leverage or not.

From macroeconomic factors, Gross Domestic Product (GDP) growth rate, inflation, stock and bond market development have been found to be theoretically relevant for banks leverage. Hypothetically, when GDP falls banks may face increase in loan default which negatively hits earnings of banks characterized by decrease in capital. Also, with low GDP banks face difficulty in raising further equity from market (Danielsson et al., 2001). There is another explanation of GDP and bank capital relationship as Berger and Udell (2004) assert that in case of high GDP the demand of bank loan also increases as compared to supply of loans which might result into decrease in banks capital. Inflation caused by increase in money supply in economy thus reducing the purchasing power of the money therefore negatively affects the savings and deposits. We can expect that inflation will lead to low bank leverage due to reduction in deposits and withdrawals. Whereas, empirically impact of inflation on deposits for CBs and IBs is contradictory, negative in case of CBs while positive for IBs (Karim et al., 2014). This may be due to the difference in nature of depositors and their expectations from IBs. As IBs have been reported to be increasing lending activities in high inflation, while depositors expect to receive higher return on their investment. Thumrongvit, Kim, and Pyun (2013) argue that with the development of bond market the credit role of bank in an economy shrinks thus affecting bank business. If a bank is operated in a country with active bond market, then bond market may substitute banks' lending to some extent. As, instead of borrowing from banks, companies with good credit ratings prefer to issue bonds to raise funds and only low rated companies that found it difficult to issue bonds will go for bank borrowings. It looks like that quality of banks loan compromises on loosing better customers (borrowers) and banks have to compromise on credit policies and standards. As quality of banking asset suffers, diminishing value of bank equity will increase debt ratio as equity market is sensitive towards risk. However, presence of developed bond market also competes with banks on supply-side. It shares savings and reduces supply of deposits for banks. Particularly certificates of deposits face competition with bonds as bonds takes away deposits from banks (Hawkins, 2002). However, it is argued that as banks possess deposit insurance (implicit and explicit), thus always preferred deposits over bond. This view predicts insignificant impact of bond market development on banks leverage.

Theoretically, development of equity/stock market directly influences debt-equity ratio in three ways. First, outside debt can be replaced with outside equity (substitution effect), which results into decrease in leverage. Secondly, stock market development may have no significant impact on leverage as outside equity substituted with inside equity results into constant debt-equity ratio. Third, impact may be ambiguous and explained with combination of other factors (e.g., existing financial structure). In third, development of stock market tends to help entrepreneurs to diversify risk and encourages further expansion. Such expansion will affect debt-equity ratio, but the effect will depend on other factors (Demirgüç-Kunt \& Maksimovic, 1996). Therefore, we clinch that underdeveloped equity or stock market 
suggests that firms probably have high debt to equity ratio. Limited access towards stock market increases dependency of firms on debt for funding their assets and investments. Equity markets also diversify risk; however, substitution of owner equity with external equity has no effect on overall debt-to-equity ratio.

However, impact of firm level factors exhibit under the umbrella of institutional factors as well as macro environmental factors embodying sensible differences in intensity and magnitude of their impact. As in the work of Chipeta and Deressa (2016), impact of profitability on leverage increases in countries with least developed stock and banking markets. This area is eye catching in research on capital structure because literature on financial decision making somehow empirically reports industry or sectoral impact on financial decisions of firms operating in the same industry (Antoniou, Guney, \& Paudyal, 2008; MacKay \& Phillips, 2005). Sectoral impact manifests in the form of industry dynamism (proxy of industry risk), industry munificence (proxy of industry growth) and industry concentration (proxy of industry competition).

Industry or sector dynamism is considered an important sector level factor which regulates level of leverage among the same sector. Li and Simerly (2002) also support this idea in their research carried out for the developed countries. Sector Dynamism in simple words is a possible uncertainty or instability of sector environment. Firms belonging to highly dynamic sectors are supposed to have high agency cost, so it is better option for them to use equity financing than that of debt. Similarly, munificence is an industrial attribute that supports regular growth, while munificent environment offers higher growth opportunities for the operating firms (Almazan \& Molina, 2005). Hence, with the expectations of bright future attributed with plenty of steady growth opportunities, firms become optimistic about regular earnings and thus increase leverage. Similar explanations may also justify the role of banking sector risk and banking sector growth on banks' leverage. Moreover, riskiness of the whole banking sector may set a trend of prudent financial behavior by increasing capital, whereas growth of the sector encourages high leverage among the banks of the same sector. Theoretical substance of industry risk (dynamism) and sector growth (munificence) have largely been explored in non-financial sector (Almazan \& Molina, 2005; Li \& Simerly, 2002).

The concentration tells us about the constitution of industry, either it is made of some large firms or by many small firms. Herfindahl index, which is the measure of level of concentration and competition within the industry has also been explored in literature of banking sector competition (Fu, Lin, \& Molyneux, 2014). In a study of financial stability of banking sector they argued that highly concentrated banking sector is more stable. Research findings suggest that in concentrated banking markets, the banks reduce credit-rationing and increase volume of loans (Caminal \& Matutes, 2002). The concentrated market allow them to charge high which results into high perception of risk among borrowers and escalation in non-performing loan (Boyd \& De Nicolo, 2005). The concentration may reduce banks leverage under afore mentioned arguments. Whereas, contrary to this, competition cuddles liquidity and value of bank equity diminishes due to high loan spread thus raising the leverage ratio (DeAngelo \& Stulz, 2013). 


\section{METHODOLOGY}

The study works with dynamic model (System GMM) to explore the existence of target leverage across financial sector of Pakistan and to measure the variation in the speed of adjustment across IBs and CBs. In accordance with the dynamic framework, the study observes the dynamics of the association between the exogenous variables and financial leverage of banking sector. It performs investigation over a period of 2006 to 2018 to explore behavior of financial leverage across conventional and IBs. For this purpose data was collected from financial statement analysis of financial sector published by SBP which was available up to financial year 2017. The data for year 2018 was collected directly from financial reports of all 29 banks from their websites. Use of static modeling supports to align and compare with empirical literature on factors of financial leverage of banking sector. The dynamic estimation provides more efficient estimation and further explains whether financial leverage of banks is dynamic in nature or not.

Different measures of capital structure are being used in relevant literature which are broadly classified in two broad categories a) Book value measures and b) Market value measures. It is decided to relay on book value measures because book value leverage is reported to be more authentic in literature (Graham \& Harvey, 2001). Moreover, regulatory requirement of capital pertains to book value of capital, and the managers are also concerned about book value of debt or leverage while making strategic decisions about capital structure. Empirically, selection of book leverage is also justified as Naveed, Ramakrishnan, Anuar, and Mirzaei, (2015) argued that book leverage was more vital in capital structure decision, because market value of debt and equity was not fully controlled by the firms. Additionally, Grop and Heider (2010) were unable to find significant differences in results for both book leverage and market leverage in a sample of banks. Therefore, due to comparative prominence and accessibility, we rely on book leverage in our study.

\section{Overview and Pertinence of Dynamic Estimation}

There are some shortcomings in static capital structure models, and dynamic model has been proposed to address the limitations effectively. Gaud, Jani, Hoesli, and Bender (2005) also supported dynamic view and prefered dynamic analysis in order to capture dynamics of capital structure and speed of adjustment in Swiss non-financial companies. Static trade-off model ignores dynamic shocks and assumes capital structure to be optimal, but due to market inefficiencies and adjustment cost, the capital structure may not necessarily be optimal all the time (Myers \& Majluf, 1984). Similarly, from econometric point of view, OLS and fixed-effect estimation may result into severe biases when dealing with dynamic nature of leverage and speed of adjustment for panel data. As per literature, we expect that like other firms, banks leverage is also explained by their lagged values; so, the use of dynamic analysis for banks leverage is justifiable. Capital structure of the firm is a dynamic phenomenon as the historical position of capital structure of a firm also contributes in determining current debt or leverage ratio. Trade-off theory of capital structure assumes target debt ratio and from the perspective of dynamic trade-off theory, current capital structure may not be optimal. The firms try to adjust towards optimal target leverage when adjustment cost is lower than the 
cost of being un-adjusted.

The variable of interest (debt to asset ratio) is dynamic in nature and the strong correlation between error term and dependent variable in analysis confirms the issue of endogeneity. Whereas, GMM estimation technique controls endogeneity and is effective for problems of omitted variables and unobserved heterogeneity. In this study, a system dynamic GMM estimation is being used as suggested by Roodman (2009). According to Roodman (2009), a system GMM estimation is preferred when coefficient of difference GMM is biased below fixed effect estimation and panels have fixed effect with heteroscedasticity and endogeneity.

For our analysis, we first run OLS and Fixed effect regression estimation individually for all level factors (firm, macro, Sector) and then combine all level factors into single equation for static regression models. OLS and fixed effect regression results of models incorporated all level factors and are reported just to facilitate comparison of results with previous literature. Hence, equations 1 and 2 represent static estimation model i.e., OLS regression and Fixed Effect estimation to investigate relationship between financial leverage and at firm, sector and country-level factors.

$$
\begin{aligned}
& \beta_{0}+\beta_{1}(\mathrm{SIZE})_{\mathrm{it}}+\beta_{2}(\mathrm{PROF})_{\mathrm{it}}+\beta_{3}(\mathrm{TANG})_{\mathrm{it}}+\beta_{4}(\mathrm{GROW})_{\mathrm{it}}+\beta_{5}(\mathrm{NDTS})_{\mathrm{it}}+ \\
\mathrm{LEV}_{i t}= & \beta_{6}(\mathrm{DIV})_{i t}+\beta_{7}(\mathrm{GDP})_{t}+\beta_{8}(\mathrm{BMKT})_{t}+\beta_{9}(\mathrm{SMKT})_{t}+\beta_{10}(\mathrm{INFL})_{t}+ \\
& \beta_{11}(\mathrm{DYN})_{\mathrm{st}}+\beta_{12}(\mathrm{MUN})_{\mathrm{st}}+\beta_{13}(\mathrm{HHI})_{\mathrm{st}}+\varepsilon_{\mathrm{it}}
\end{aligned}
$$

$$
\begin{aligned}
& \beta_{0}+\beta_{1}(\mathrm{SIZE})_{\mathrm{it}}+\beta_{2}(\mathrm{PROF})_{\mathrm{it}}+\beta_{3}(\mathrm{TANG})_{\mathrm{it}}+\beta_{4}(\mathrm{GROW})_{\mathrm{it}}+\beta_{5}(\mathrm{NDTS})_{\mathrm{it}}+ \\
\mathrm{LEV}_{i t}= & \beta_{6}(\mathrm{DIV})_{i t}+\beta_{7}(\mathrm{GDP})_{t}+\beta_{8}(\mathrm{BMKT})_{t}+\beta_{9}(\mathrm{SMKT})_{t}+\beta_{10}(\mathrm{INFL})_{t}+ \\
& \beta_{11}(\mathrm{DYN})_{\mathrm{st}}+\beta_{12}(\mathrm{MUN})_{\mathrm{st}}+\beta_{13}(\mathrm{HHI})_{\mathrm{st}}+\mu_{i}+\mu_{t}+\varepsilon_{\mathrm{it}}
\end{aligned}
$$

However, more efficient system Dynamic panel data analysis technique is being applied and reported for each level (firm, macro, Sector) of factors. Moreover, we primarily draw our findings and conclusions based on dynamic analysis because OLS and fixed effect analysis have severe limitations in dealing with panel data. So, in case of dynamic estimation we breakdown the model into three step models. M1 includes only bank specific factors, M2 retains macroeconomic variables and M3 is based on sector level variables. Equations 3, 4 and 5 represent dynamic estimation to investigate relationship between financial leverage and at firm, macro and sector level factors, respectively.

$$
\begin{aligned}
& \Delta \mathrm{LEV}_{\mathrm{it}}= \begin{array}{l}
\beta_{0}+(1-\lambda) \mathrm{Dit}-1+\beta 1(\mathrm{SIZE})_{\mathrm{it}}+\beta 2(\mathrm{PROF})_{\mathrm{it}}+\beta 3(\mathrm{TANG})_{\mathrm{it}}+ \\
\beta 4(\mathrm{GROW})_{\mathrm{it}}+\beta 5(\mathrm{NDTS})_{\mathrm{it}}+\beta 6(\mathrm{DIV})_{\mathrm{it}}+\mu_{\mathrm{i}}+\mu_{t}+\varepsilon_{\mathrm{it}}
\end{array} \\
& \Delta \mathrm{LEV}_{\mathrm{it}}=\begin{array}{l}
\beta_{0}+(1-\lambda) \mathrm{Dit}-1+\beta 1(\mathrm{GDP}) \mathrm{t}+\beta 2(\mathrm{BMKT}) \mathrm{t}+\beta 3(\mathrm{SMFT}) \mathrm{t}+ \\
\beta 4(\mathrm{INFL}) \mathrm{t}+\mu \mathrm{i}+\mu \mathrm{t}+\mathrm{sit}
\end{array} \\
& \Delta \mathrm{LEV}_{\mathrm{it}}=\begin{array}{l}
\beta_{0}+(1-\lambda) \mathrm{Dit}-1+\beta 1(\mathrm{DYN}) \mathrm{st}+\beta 2(\mathrm{MUN}) \mathrm{st}+\beta 3(\mathrm{HHI}) \mathrm{st}+ \\
\mu \mathrm{i}+\mu \mathrm{t}+\varepsilon \mathrm{it}
\end{array}
\end{aligned}
$$


Where,
LEV = Book Value of total Leverage
BMKT $=$ Bond Market Development
Dit-1 = Lag Value of Leverage
SMKT $=$ Stock Market Development
SIZE $=$ Size of Bank
INFL = Inflation (Consumer Price Index)
PROF = Profitability
DYN = Dynamism
TANG $=$ Tangibility
MUN = Munificence
GROW = Growth
$\mathrm{HHI}=$ Concentration $(\mathrm{H}-\mathrm{H}$ Index $)$
NDTS $=$ Non Debt Tax Shield
$\mu \mathrm{i}=$ Time-invariant unobserved fixed-effect
DIV $=$ Dividend
$\mu \mathrm{t}=$ Firm-invariant time-specific effect
GDP $=$ Gross Domestic Product
$\varepsilon$ it $=$ Disturbance Term

\section{RESULTS AND DISCUSSION}

Starting with descriptive statistics for each level factors, a series of diagnostic and robustness tests were performed. Stationarity of each series was examined using unit root tests for panel dataset. In order to detect multicollinearity issue, Variation Inflation Factor (VIF) has been calculated which remained less than 2 for individual variables, while the mean VIF is 1.87.

TABLE 1

Summary Statistics of Financial Leverage and Main Variables in Financial Sector of Pakistan and Total Leverage (Total Debt/Total Asset) of Commercial Banks

\begin{tabular}{lllllllllllll}
\hline \hline & \multicolumn{3}{c}{ Overall Banking Sector } & \multicolumn{4}{c}{ CBs } & \multicolumn{4}{c}{ IBs } \\
\cline { 2 - 12 } Factor & Mean & S.D. & Min & Max & Mean & S.D. & Min & Max & Mean & S.D. & Min & Max \\
\hline LEV & .834 & .079 & 0.78 & .862 & 0.837 & 0.080 & 0.818 & 0.850 & 0.820 & 0.076 & 0.456 & 0.930 \\
SIZE & 15.9 & 1.661 & 7.63 & 18.8 & 16.1 & 1.64 & 7.625 & 18.78 & 14.9 & 0.58 & 9.7 & 19.3 \\
PROF & 0.003 & 0.027 & -0.222 & 0.183 & 0.004 & 0.029 & -0.222 & 0.183 & -0.002 & 0.001 & -0.05 & 0.018 \\
TANG & 0.036 & 0.044 & 0.004 & 0.275 & 0.034 & 0.045 & 0.001 & 0.275 & 0.044 & 0.033 & 0.011 & 0.268 \\
GROW & 0.233 & 0.531 & -0.836 & 6.46 & 0.189 & 0.510 & -0.836 & 6.463 & 0.448 & 0.58 & -0.36 & 2.62 \\
NDTS & 0.002 & 0.002 & $5.66 \mathrm{e}-$ & 0.018 & 0.002 & 0.001 & $5.70 \mathrm{e}-$ & 0.017 & 0.005 & 0.003 & 0.001 & 0.018 \\
& & & 006 & & & & 006 & & & & & \\
DIV & 0.428 & 0.496 & 0.00 & 1.00 & 0.479 & 0.5 & 0.00 & 1.00 & 0.180 & 0.388 & 0.00 & 1.00 \\
GDP & .037 & 0.141 & 0.016 & 0.061 & 0.037 & 0.014 & 0.016 & 0.061 & 0.037 & 0.014 & 0.016 & 0.061 \\
BMKT & .466 & 0.026 & 0.422 & 0.512 & 0.466 & 0.026 & 0.422 & 0.512 & 0.466 & 0.027 & 0.421 & 0.512 \\
SMKT & .276 & 0.091 & 0.149 & 0.414 & 0.276 & 0.091 & 0.149 & 0.414 & 0.276 & 0.091 & 0.149 & 0.414 \\
INFL & .1 & 0.034 & 0.17 & 0.17 & 0.1 & 0.034 & 0.045 & 0.17 & 0.1 & 0.034 & 0.045 & 0.17 \\
DYN & .024 & 0.001 & 0.023 & 0.027 & 0.025 & 0.001 & 0.023 & 0.027 & 0.024 & 0.001 & 0.023 & 0.027 \\
MUN & .055 & 0.005 & 0.044 & 0.065 & 0.056 & 0.005 & 0.044 & 0.064 & 0.055 & 0.005 & 0.044 & 0.064 \\
HHI & .081 & 0.004 & 0.093 & 0.093 & 0.081 & 0.004 & 0.076 & 0.093 & 0.081 & 0.004 & 0.076 & 0.093 \\
Count & 377 & 377 & 377 & 377 & 312 & 312 & 312 & 312 & 65 & 65 & 65 & 65 \\
\hline \hline
\end{tabular}

Note: Dependent variable is Financial Leverage (LEV): independent factors include size, Profitability (PROF), Tangibility (TANG), Growth Opportunities (GROW), Non-Debt Tax Shield (NDTS), Dividend (DIV), GDP Growth Rate (GDP), Bond Market Development (BMKT), Stock Market Development (SMKT), Inflation Rate (INFL), Sector Dynamism (DYN), Sector Munificence (MUN) and Sector Concentration HH Index (HHI).

\section{Leverage Trend in Banking Sector}

This section of results and discussions contains trend analysis of dependent variables i.e., financial Leverage in banking sector of Pakistan. Figure 1 shows leverage trend of overall 
banking sector over a period of 13 years. For the study period, financial sector leverage ratio ranged between $78 \%$ (2006) to $86 \%$ (2015). While for the CBs, it ranged from $81.7 \%$ (2014) to $85 \%(2010)$.

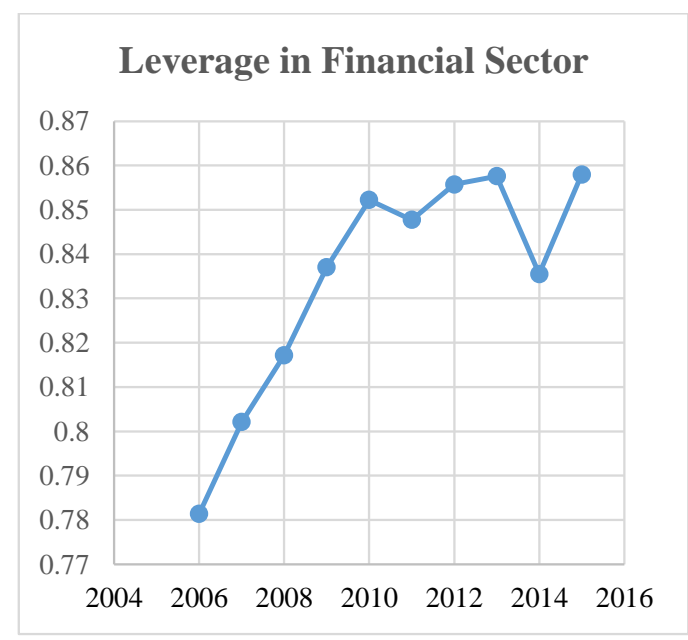

FIGURE 1. Leverage in financial sector

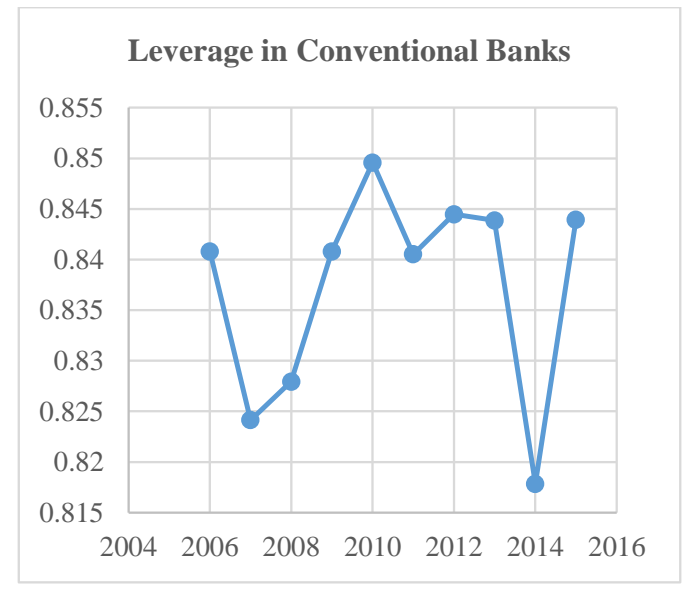

FIGURE 2. Leverage in conventional banks

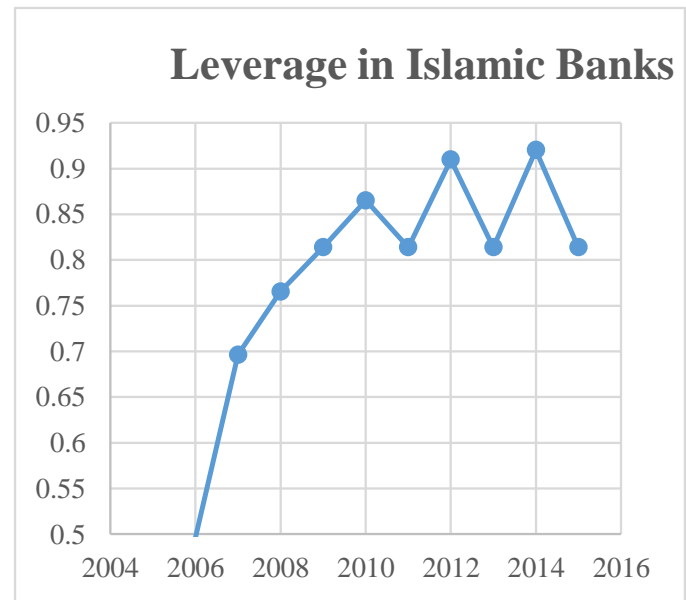

FIGURE 3. Leverage in Islamic banks 
Wherein, Figure 3 shows trend of financial leverage in IBs that is quite interesting. From 2006 to 2010 there is a continuous increase in financial leverage of IBs. Although this period includes crisis period; however, increase of leverage in IBs may be due to their steady growth during this period. For 2012 (91\%) and 2014 (93\%), leverage of IBs was higher than that of CBs, respectively.

\section{Results of Static Modeling}

Table 2 compares the results of OLS regression and fixed effect analysis with total leverage as dependent variable. Results of overall banking sector indicate that bank size is significantly and positively related to leverage in both models with coefficient 0.078 and 0.047 respectively. It shows that one-unit increase in firm size results in 0.078 unit increase in leverage according to OLS regression. Whereas, profitability and asset tangibility result into significant negative relationships with total leverage for overall banking sector, which indicate that increase in these variables decreased the leverage of Pakistani banks.

TABLE 2

OLS and Fixed Effect Regression Results for Total Debt

\begin{tabular}{lllllll}
\hline \hline \multicolumn{6}{c}{ OLS and Fixed Effect regression Results for Total Debt } \\
\hline \multirow{2}{*}{ Overall Financial } & \multicolumn{3}{c}{ CBs } & \multicolumn{2}{c}{ IBs } \\
\cline { 2 - 7 } SIZE & OLS & Fixed Effect & OLS & Fixed Effect & OLS & Fixed Effect \\
PROF & $0.078^{* * *}$ & $0.047^{* *}$ & $0.07^{* * *}$ & $0.028^{*}$ & $0.097^{* * *}$ & $0.098^{* * *}$ \\
TANG & $-1.187^{* * *}$ & $-0.704^{*}$ & -1.062 & $-0.654^{*}$ & $-2.356^{*}$ & $-3.249^{* * *}$ \\
GROW & $-0.724^{* * *}$ & $-1.917^{* * *}$ & $-0.535^{* * *}$ & $-1.474^{*}$ & $-1.559^{* * *}$ & $-2.245^{* * *}$ \\
NDTS & 0.019 & -0.001 & 0.014 & 0.001 & 0.028 & $-0.007^{*}$ \\
-DIV & 5.136 & -6.639 & $17.678^{* * *}$ & 3.885 & $-9.995^{* *}$ & $-10.974^{* * *}$ \\
GDP & -0.029 & -0.004 & -0.007 & -0.001 & -0.054 & 0.034 \\
BMKT & -1.472 & -1.565 & -1.426 & -1.257 & -2.554 & $-2.595^{*}$ \\
SMKT & -0.148 & -0.295 & -0.235 & -0.166 & -0.723 & $-1.495^{* *}$ \\
INFL & -0.104 & -0.063 & -0.090 & -0.105 & 0.121 & $0.316^{*}$ \\
DYN & 0.421 & 0.718 & 0.628 & $0.882^{*}$ & -0.536 & -0.902 \\
MUN & 68.614 & 206.280 & 67.956 & 124.154 & 323.674 & $608.962^{* *}$ \\
HHI & 6.235 & 15.932 & 5.599 & 9.875 & -90.082 & $48.339^{* *}$ \\
COUNT & -21.362 & -64.025 & -21.539 & -41.547 & -2.201 & $-174.236^{* *}$ \\
Adj. R & 377 & 377 & 312 & 312 & 65 & 65 \\
$F$-statistics & 0.507 & & 0.493 & & 0.879 & \\
Durbin-Watson & $25.45^{* * *}$ & $22.35 * * *$ & $35.01 * * *$ & $17.84 * *$ & $29.62^{* * *}$ & $25.43^{* * *}$ \\
\hline \hline
\end{tabular}

Note: Dependent variable: Leverage (Total Debt/Total Asset), the reported coefficients are based on robust standard errors estimation Significant at $10 \%$ level

*Significant at $5 \%$ level

**Significant at $1 \%$ level

In case of conventional banking sector size is positively related to leverage with coefficient 0.07 and $p$-value of 0.0005 . Profitability and tangibility are negative in sample of conventional banking as well as in Islamic banking. Profitability in Islamic banking results into higher coefficient value and is more significant as compared to conventional banking sector. 
TABLE 3

Summary of Key Findings and Significant Factors of Leverage Based on Static Estimation Methods

\begin{tabular}{llll}
\hline \hline Estimation Model & Overall Sample & CBs & IBs \\
\hline Simple OLS (static) & $\begin{array}{l}\text { Size, Profitability, } \\
\text { Tangibility }\end{array}$ & $\begin{array}{l}\text { Size, Tangibility, } \\
\text { NDTS }\end{array}$ & Size, Profitability, Tangibility, NDTS \\
Fixed Effect (static) & $\begin{array}{l}\text { Size, Profitability, } \\
\text { Tangibility }\end{array}$ & $\begin{array}{l}\text { Profitability, Tangibility, } \\
\text { Inflation }\end{array}$ & $\begin{array}{l}\text { Size, Profitability, Tangibility, Growth op- } \\
\text { portunity, NDTS, GDP, Bond market de- } \\
\text { velopment, Stock market development, } \\
\end{array}$ \\
& & $\begin{array}{l}\text { Sector Dynamism, Sector Munificence, } \\
\text { Sector Concentration }\end{array}$ \\
\hline \hline
\end{tabular}

In static regression modeling, result for NDTS is quite ambiguous; in CBs, NDTS is positively associated with leverage and in IBs it is negative. A negative relationship is consistent with trade-off-theory according to which firms with comparatively low NDTS increase their debt level for tax-benefits in real markets. As firm with more NDTS results into high depreciation or tax credits of investment and tax benefits of firm from NDTS reduce the firms' motivation to use debt for tax benefit purpose. However, high NDTS (depreciation/asset) represents quality of bank asset that contributes towards reducing risk and increases leverage capacity. Empirical literature also reports positive relationship between NDTS and leverage (Bradley, Jarrell, \& Kim, 1984). Moreover, NDTS is not only a measure of tax benefits, but also in the form of depreciation confirms the presence of tangible assets. So, high depreciation means more tangible assets that support more debt.

In CBs, only inflation rate is significantly associated with bank leverage whereas in IBs, GDP and bond market development are negatively associated with bank leverage, while association of stock market development is positive but less significant. CBs increase their leverage when economy prevails high inflation rate and IBs increase their leverage level when economy results into low GDP growth rate and low bond market development. In OLS model it is assumed that all cross-sectional units (firms) are similar and cross sectional differences have no impact on leverage. While, by controlling the time-variant and firm-variant impacts, the fixed effect model revealed different sets of significant factors. Aligned with the objectives of the study, more efficient dynamic model (System GMM) is further used to explore the existence of target leverage and to highlight the variation in the speed of adjustment across Islamic and CBs.

\section{Results of Dynamic Modeling}

Table 4 represents results of dynamic panel data estimation for overall commercial banking sector and separately for both conventional and IBs. The most prominent observation is that the leverage of financial sector is also dynamic in nature. Lag value of leverage is highly significant in all reported cases. Profitability, tangibility, inflation and sector concentration are significant factors for CBs while size, profitability, growth opportunity, tax shield, GDP and sector concentration are significant determinants of IBs leverage.

In order to ensure the validity and robustness of estimated results we performed GMM diagnostic tests for instruments validity and for error term autocorrelation. Insignificant value of Sargan test supports the choice of instruments, while insignificant value of AR (1) and 
AR (2) tests ensure that error term is uncorrelated. Sargan and Hansen J test is used to check the validity and health of instruments. Results for overall and for sample of CBs validate the health of instruments used. However, the number of observations in case of IBs sample are on lower side so using a large sample of IBs could further improve generalizability of results.

In dynamic analysis it is obvious that leverage of banking sector is also dynamic in nature. Study also substantiates the research significance of nature of sector for financial leverage in both IBs and CBs. Comparative analysis between Islamic and CBs also discovers very interesting results for each level of factors. Speed of adjustment is comparatively far less for IBs than that of CBs. From firm level factors, impacts of size, profitability and growth opportunities are more pronounced in IBs; while for CBs, size, tangibility and profitability are core determinants in our sample. Sector level concentration affects leverage in both categories of banks while impacts of munificence and dynamism are not significant in dynamic analysis results. However from macroeconomic factors, inflation has impact on CBs leverage, whereas GDP is main determinant for IBs leverage.

TABLE 4

Dynamic Panel Data Analysis

\begin{tabular}{llllllllll}
\hline \hline & \multicolumn{2}{l}{ Overall Banking Sector } & \multicolumn{2}{l}{ CBs } & \multicolumn{2}{l}{ IBs } \\
\hline Variables & M1 & M2 & M3 & M1 & M2 & M3 & M1 & M2 & M3 \\
\hline TD(-1) & $0.651^{* * *}$ & $0.906^{* * *}$ & $0.908^{* * *}$ & $0.692^{* * *}$ & $0.981^{* * *}$ & $0.979^{* * *}$ & $0.432^{* *}$ & $0.528^{* *}$ & $0.524^{* *}$ \\
SIZE & $0.036^{* *}$ & & & $0.0217^{*}$ & & & $0.0311^{* *}$ & & \\
PROF & $-0.811^{* *}$ & & & $-0.857^{* * *}$ & & & $-0.699^{*}$ & & \\
TANG & $-0.284^{*}$ & & & $-0.369^{* *}$ & & & 0.217 & & \\
GROW & 0.0233 & & & 0.00147 & & & $0.0338^{*}$ & & \\
NDTS & 2.897 & & & 4.159 & & & -9.097 & & \\
DIV & 0.00593 & & & -14.153 & & & 0.0096 & & \\
GDP & & $-0.620^{*}$ & & & -0.524 & & & $0.603^{*}$ & \\
BMKT & & 0.0140 & & & 0.135 & & & 0.0636 & \\
SMKT & & 0.0272 & & & 0.0127 & & & -0.151 & \\
INFL & & -0.0914 & & & $1.485^{*}$ & & & -0.251 & \\
DYN & & & -10.81 & & & 84.57 & & & -26.69 \\
MUN & & & -2.089 & & & 9.797 & & & -2.810 \\
HHI & & & $-5.341^{* *}$ & & & $-42.78^{* *}$ & & & $-5.876^{*}$ \\
AR(1) & 0.11 & 0.17 & 0.18 & 0.19 & 0.17 & 0.18 & 0.15 & 0.27 & 0.31 \\
AR(2) & 0.44 & 0.46 & 0.60 & 0.40 & 0.97 & 0.58 & 0.22 & 0.23 & 0.38 \\
Sargan Test & 11.54 & 43.40 & 43.79 & 11.87 & 35.18 & 36.51 & 10.58 & 45.77 & 46.12 \\
Hansen J & 0.14 & 0.098 & 0.12 & 0.25 & 0.35 & 0.24 & 0.91 & 0.87 & 0.89 \\
\hline
\end{tabular}

Note: Dependent variable: Leverage (Total Debt/Total Asset), the reported coefficients are based on system xtabond2 (dynamic estimation) by Roodman (2009) with robust and collapse option. AR (1), AR (2) are tests for first and second order serial correlation respectively, asymptotically $\mathrm{N}(0,1)$. Sargan (chi2) and Hansen ( $p$-value) tests of over identifying restrictions

Significant at $10 \%$ level

*Significant at $5 \%$ level

$* *$ Significant at $1 \%$ level

In a sample from banks in Pakistan, the factor of size predicts positive and significant relationship with the bank leverage for both conventional as well as IBs. Consistent with the predictions of agency theory, which states that large firms face more agency problems. Therefore, large firms use leverage as a control mechanism and to cater opportunistic behavior of managers. Results are also consistent with some bank based empirical studies, e.g., Gropp and Heider (2010) report significant positive relationship between bank size and bank leverage. 
Theory argues that larger banks are well diversified in term of borrowings and lendings. Large banks capture diversified regions and markets hence their idiosyncratic risk is comparatively less, requiring less precautionary capital to maintain.

Another very significant bank specific factor is profitability which is negatively associated with bank leverage and is supported by the corporate literature of non-financial firms. According to banks buffer view of capital structure, impact of profitability theoretically should be positive. The banks with high profitability are less likely to maintain buffer and comparatively increase their leverage. Whereas, empirical results of relationship between bank profitability and bank capital have show significant positive relationship in some studies indicating that banks with higher profits maintain more capital (Gropp \& Heider, 2010). Therefore, bank leverage ratio is negatively associated with profitability of banks and similar pattern is also observed in our study. These results are coherent with pecking order theory of capital structure which exhibits negative association between profitability and level of debt (Chipeta \& Deressa, 2016).

TABLE 5

Summary of Key Findings and Significant Factors of Leverage Based on Dynamic Estimation Methods

\begin{tabular}{|c|c|c|c|}
\hline Estimation Model & Overall Sample & $\mathrm{CBs}$ & IBs \\
\hline Lag leverage & $\begin{array}{l}\text { Significant (dynamic in na- } \\
\text { ture) }\end{array}$ & $\begin{array}{l}\text { Significant (dynamic in na- } \\
\text { ture) }\end{array}$ & $\begin{array}{l}\text { Significant (dynamic in na- } \\
\text { ture) }\end{array}$ \\
\hline Significant Factors & $\begin{array}{l}\text { Size (+), Profitability (-), } \\
\text { Tangibility(-),GDP(+), Sec- } \\
\text { tor Concentration (-) }\end{array}$ & $\begin{array}{l}\text { Size (+), Profitability (-), } \\
\text { Tangibility(-), Inflation(+), } \\
\text { Sector Concentration (-) }\end{array}$ & $\begin{array}{l}\text { Size (+), Profitability (- } \\
) \text {, Growth opportunity }(+) \text {, } \\
\text { GDP }(+) \text {, Sector Concentra- } \\
\text { tion }(-)\end{array}$ \\
\hline Speed of Adjustment & 19 Months & 23 Months & 10 Months \\
\hline
\end{tabular}

In our sample of banks, tangibility is negatively related with bank leverage in CBs, while insignificant in sample of IBs. Theoretically, a positive relationship between tangible assets and level of debt is assumed. The firms with higher research and development and advertising expenditures tend to avoid debt because intangible assets' return has long life and takes relatively very long time to realized. However, Almeida and Campello (2007) argue that tangibility is less important for the firms that are not financially constrained. IBs are enjoying good reputation due to stable earnings during financial crisis and expected to have less credit constraints. So, it could be the reason of insignificant impact of tangibility for IBs.

Growth opportunity has reported a positive significant relationship with leverage only for IBs. Theoretically, from the perspective of pecking order theory, this relationship is positive because firms try to realize the opportunity and often need additional debt to meet the investment expenses; hence, the level of leverage goes up (Naveed et al., 2015). Similarly, in line with literature, GDP growth rate represents positive relationship with bank leverage. Rationale behind this positive relationship is that during growth and stability period, firms earn more profit that is expected to be less volatile. Further, firms have ability to pay back regular debt payments. So, instead of sharing profit and control (options associated with equity), they might prefer taking debt to maximize profit of existing shareholders as consistent with trade off theory. Positive inflation-leverage relationship can be explained by market timing theory; during the time of inflation equity of the firm becomes undervalued, so 
mangers go for debt predicting positive relationship with leverage (Frank \& Goyal, 2009).

As expected, banks with lower concentration and higher competition within banking sector tend to maintain higher leverage. Seminal research findings suggest that in concentrated bank markets banks reduce credit-rationing and increase volume of loans (Caminal \& Matutes, 2002). The concentrated market allows them to charge high which may results into high perception of risk for borrowers and escalation in non-performing loans (Boyd \& De Nicolo, 2005). Similarly, DeAngelo and Stulz (2013) argued that competition cuddles liquidity and value of bank equity diminishes with low concentration. Diminishing value of equity and high loan spread raise leverage ratio of banks.

From above analysis and discussions it is obvious that banks capital structure is not solely determined by regulatory or buffer view; instead corporate finance theories of capital structure somehow hold for banking sector as well. Leverage of banks, like non-financial firms, also has some targeted structure and is dynamic in nature. Dynamic nature of leverage and presence of targeted structure validate the existance of some speed of adjustment to meet the targeted leverage ratio.

\section{Speed of Adjustment}

Dynamic nature of leverage for financial sector of Pakistan is substantiated in results and discussions of Table 4. However, significant dynamic nature of financial leverage maintains an argument of targeted financial leverage from which current level of leverage is deviated. Hence, Table 5 addresses the sub objective of the study and calculates speed of adjustment towards its targeted financial leverage for financial sector of Pakistan.

\section{TABLE 6}

Speed of Adjustment and Half-Life (Years, Months) for Financial Sector of Pakistan

\begin{tabular}{lllllll}
\hline \hline Sample & $(1-\lambda)$ & $\lambda$ & $\log (0.5)$ & $\log (1-\lambda)$ & $\log (0.5) / \log (1-\lambda)$ & Half Life \\
\hline Overall Banking Sector & 0.651 & 0.349 & -0.301 & -0.1864 & 1.615 years & 19 Month \\
CBs & 0.692 & 0.308 & -0.301 & -0.1599 & 1.882 years & 23 Month \\
IBs & 0.432 & 0.568 & -0.301 & -0.3645 & 0.826 year & 10 Month \\
\hline
\end{tabular}

Table presents estimated annual Speed of Adjustment (SOA) towards target leverage using panel data for the period of 12 years from 2006 to 2018. The speed of adjustment is given by $\lambda$. Half-life is the number of months that the SOA implies for a firm to move half way toward its target Financial Leverage.

Here, IBs have an advantage as compared to CBs. IBs have half-life of only 10 months (0.826 year) for adjustment of their leverage. It means that IBs would take 9 months to achieve their target level of financial leverage. While, CBs have very slow speed of adjustment so CBs would take 23 months (1.882 years) to adjust their financial leverage. Additionally, overall banking sector of Pakistan have half-life of 19 months (1.615 years) that is 4 months less than that of CBs and 9 months more to half-life of IBs. Also, the differences in speed of adjustment is well described by Guney, $\mathrm{Li}$, and Fairchild (2011), a firm adjust with slower speed if the firm faces high adjustment cost, while with lower cost of adjustment a firm has faster speed of adjustment towards its target capital structure or debt ratio. Hence, from this trade-off between adjustment cost and firm cost of being off the target leverage CBs appeared to face higher adjustment cost. This difference may be because of tough competition 
conventional banking is facing due to increasing popularity of Islamic banking in Pakistan. But for IBs, adjustment in current leverage ratio is comparatively easy and less costly.

Our study results indicate deviation from textbook theory of banks capital structure and with the help of a sophisticated model it illustrates that banking sector also optimizes and adjusts capital structure for environmental shocks and variations. Our findings are thus free from potential biases inherited in panel data and induced by omitted variables and unobserved heterogeneity or simultaneity.

\section{CONCLUSION}

Our study results into deviation from textbook theory of banks capital structure and with the help of a sophisticated model it illustrates that banks optimise and adjust their capital structure as the non-financial sector. Deviation of capital ratio from regulatory capital is also proved by the work of Flannery and Rangan (2008), while Gropp and Heider (2010) endorse that first order determinants of capital structure are the factors proposed by corporate finance theory rather than regulatory requirements. Moreover, financial leverage of banking sector is also found to be dynamic in nature i.e., influenced by lag value of leverage. Study also substantiates the research significance regarding behavior of financial leverage in both IBs and CBs.

Differentiation of results for conventional versus IBs and effect of sectoral factors revealed by the results might be useful for investors, debtors and financial managers to understand the financial behavior of banks as a unit of particular type of banking system. Moreover, this study would help financial market policy makers and the mangers of both Islamic and CBs by providing more insights about behavior of financial leverage of banking firms. This study results into noteworthy contribution in literature of nexus between theory relevance and irrelevance for banks' capital structure decision. The analysis and discussion implies that banks capital structure is not solely determined by regulatory or buffer view, and the corporate finance theories of capital structure are also valid for the banking sector. It also enriches the scarce literature on determinants of IBs capital structure, especially with the inclusion of sector level dynamism, concentration and munificence.

Thus, we have two different sectoral environment; one is more dynamic i.e., CBs in case of which shocks absorbing time by the study tend to be more (1.88 years) and is more sluggish, as compared to IBs in case of which economic shocks and financial variations tend to maintain adjustments in 0.82 year. Comparatively Islamic banking leverage tends to be more responsive to make adjustments, while the conventional banking sector in Pakistan is relatively sluggish. Hence, the study provides implications associated with deposits revenue and suggests revisiting the models of risk management that would capture and incorporate dynamic variations. Limitations of the study are time and data constraints; so for future research similar study can be conducted for a large sample of IBs. Moreover, inclusion of sample from developed countries would enhance generalizability. 


\section{REFERENCES}

Abedifar, P., Molyneux, P., \& Tarazi, A. (2013). Risk in Islamic banking. Review of Finance, 17(6), 2035-2096. doi: https://doi.org/10.1093/rof/rfs041

Alkhazaleh, A. M., \& Almsafir, M. K. (2015). Does asymmetry of information drive banks' capital structure? Empirical evidence from Jordan. International Journal of Economics and Finance, 7(3), 86-97. doi: https://doi.org/10.5539/ijef.v7n3p86

Allen, F., Fulghieri, P., \& Mehran, H. (2011). The value of bank capsital and the structure of the banking industry. Review of Financial Studies, 24(4), 971-982.

doi: https://doi.org/10.1093/rfs/hhr003

Almazan, A., \& Molina, C. A. (2005). Intra-industry capital structure dispersion. Journal of Economics $\mathcal{E}$ Management Strategy, 14(2), 263-297.

doi: https://doi.org/10.1111/j.1530-9134.2005.00042.x

Almeida, H., \& Campello, M. (2007). Financial constraints, asset tangibility, and corporate investment. Review of Financial Studies, 20(5), 1429-1460.

doi: https://doi.org/10.1093/rfs/hhm019

Antoniou, A., Guney, Y., \& Paudyal, K. (2008). The determinants of capital structure: Capital market-oriented versus bank-oriented institutions. Journal of Financial and Quantitative Analysis, 43(01), 59-92. doi: https://doi.org/10.1017/S0022109000002751

Berg, T., \& Gider, J. (2017). What explains the difference in leverage between banks and nonbanks? Journal of Financial and Quantitative Analysis, 52(6), 2677-2702. doi: https://doi.org/10.1017/S0022109017000734

Berger, A. N., Hasan, I., \& Zhou, M. (2009). Bank ownership and efficiency in China: What will happen in the world's largest nation? Journal of Banking $\mathcal{F}$ Finance, 33(1), 113-130. doi: https://doi.org/10.1016/j.jbankfin.2007.05.016

Berger, A. N., \& Udell, G. F. (2004). The institutional memory hypothesis and the procyclicality of bank lending behavior. Journal of Financial Intermediation, 13(4), 458-495. doi: https://doi.org/10.1016/j.jfi.2004.06.006

Bertrand, M., \& Schoar, A. (2003). Managing with style: The effect of managers on firm policies. The Quarterly Journal of Economics, 118(4), 1169-1208.

doi: https://doi.org/10.1162/003355303322552775

Boyd, J. H., \& De Nicolo, G. (2005). The theory of bank risk taking and competition revisited. The Journal of Finance, 60(3), 1329-1343. doi: https://doi.org/10.1111/j.1540-6261.2005.00763.x

Bradley, M., Jarrell, G. A., \& Kim, E. H. (1984). On the existence of an optimal capital structure: Theory and evidence. The Journal of Finance, 39(3), 857-878. doi: https://doi.org/10.1111/j.1540-6261.1984.tb03680.x

Caminal, R., \& Matutes, C. (2002). Market power and banking failures. International Journal of Industrial Organization, 20(9), 1341-1361.

doi: https://doi.org/10.1016/S0167-7187(01)00092-3

Cannata, F., \& Quagliariello, M. (2009). The role of Basel II in the subprime financial crisis: guilty or not guilty? (CAREFIN research paper no. 3/09). Milan, Italy: Carefin, Università Bocconi 
Chipeta, C., \& Deressa, C. (2016). Firm and country specific determinants of capital structure in Sub Saharan Africa. International Journal of Emerging Markets, 11(4), 649-673. doi: https://doi.org/10.1108/IJoEM-04-2015-0082

Danielsson, J., Embrechts, P., Goodhart, C., Keating, C., Muennich, F., Renault, O., \& Shin, H. S. (2001). An academic response to Basel II (Special paper no. 30). London, UK: LSE Financial Markets Group.

DeAngelo, H., \& Stulz, R. M. (2013). Why high leverage is optimal for banks (No. w19139). Cambridge, MA: National Bureau of Economic Research.

doi: https://doi.org/10.3386/w19139

Demirgüç-Kunt, A., \& Maksimovic, V. (1996). Stock market development and financing choices of firms. The World Bank Economic Review, 10(2), 341-369.

doi: https://doi.org/10.1093/wber/10.2.341

Diamond, D. W., \& Rajan, R. G. (2000). A theory of bank capital. The Journal of Finance, 55(6), 2431-2465. doi: https://doi.org/10.1111/0022-1082.00296

Engelen, K. C. (2005). BIS birthday blues. The International Economy, 19(4), 46-51.

Flannery, M. J., \& Rangan, K. P. (2008). What caused the bank capital build-up of the 1990s? Review of Finance, 12(2), 391-429. doi: https://doi.org/10.1093/rof/rfm007

Frank, M. Z., \& Goyal, V. K. (2007). Corporate leverage: How much do managers really matter? Retrieved from https://bit.ly/37jhZbh

Frank, M. Z., \& Goyal, V. K. (2009). Capital structure decisions: Which factors are reliably important? Financial Management, 38(1), 1-37.

doi: https://doi.org/10.1111/j.1755-053X.2009.01026.x

Fu, X. M., Lin, Y. R., \& Molyneux, P. (2014). Bank competition and financial stability in Asia Pacific. Journal of Banking E Finance, 38, 64-77.

doi: https://doi.org/10.1016/j.jbankfin.2013.09.012

Gaud, P., Jani, E., Hoesli, M., \& Bender, A. (2005). The capital structure of Swiss companies: An empirical analysis using dynamic panel data. European Financial Management, 11(1), 51-69. doi: https://doi.org/10.1111/j.1354-7798.2005.00275.x

Goodhart, C., Hartmann, P., Llewellyn, D. T., Rojas-Suarez, L., \& Weisbrod, S. (2013). Financial regulation: Why, how and where now? New York, NY: Routledge.

doi: https://doi.org/10.4324/9780203350386

Graham, J. R., \& Harvey, C. R. (2001). The theory and practice of corporate finance: evidence from the field. Journal of Financial Economics, 60(2-3), 187-243. doi: https://doi.org/10.1016/S0304-405X(01)00044-7

Gropp, R., \& Heider, F. (2010). The determinants of bank capital structure. Review of Finance, 14(4), 587-622. doi: https://doi.org/10.1093/rof/rfp030

Guney, Y., Li, L., \& Fairchild, R. (2011). The relationship between product market competition and capital structure in Chinese listed firms. International Review of Financial Analysis, 20(1), 41-51. doi: https://doi.org/10.1016/j.irfa.2010.10.003

Hawkins, J. (2002). Bond markets and banks in emerging economies (BIS papers no. 11). Basel, Switzerland: Bank for International Settlements Press \& Communications. 
Jaffar, M., \& Manarvi, I. (2011). Performance comparison of Islamic and CBs in Pakistan. Global Journal of Management and Business Research, 11(1), 60-66.

Karim, M. A., Hassan, M. K., Hassan, T., \& Mohamad, S. (2014). Capital adequacy and lending and deposit behaviors of conventional and Islamic banks. Pacific-Basin Finance Journal, 28, 58-75. doi: https://doi.org/10.1016/j.pacfin.2013.11.002

Kayo, E. K., \& Kimura, H. (2011). Hierarchical determinants of capital structure. Journal of Banking \& Finance, 35(2), 358-371. doi: https://doi.org/10.1016/j.jbankfin.2010.08.015

Košak, M., Li, S., Lončarski, I., \& Marinč, M. (2015). Quality of bank capital and bank lending behavior during the global financial crisis. International Review of Financial Analysis, 37, 168-183. doi: https://doi.org/10.1016/j.irfa.2014.11.008

Laux, C., \& Rauter, T. (2017). Procyclicality of US bank leverage. Journal of Accounting Research, 55(2), 237-273. doi: https://doi.org/10.1111/1475-679X.12163

Lemma, T., \& Negash, M. (2014). Determinants of the adjustment speed of capital structure: Evidence from developing economies. Journal of Applied Accounting Research, 15(1), 64-99. doi: https://doi.org/10.1108/JAAR-03-2012-0023

Li, M., \& Simerly, R. L. (2002). Environmental dynamism, capital structure and innovation: An empirical test. The International Journal of Organizational Analysis, 10(2), 156-171. doi: https://doi.org/10.1108/eb028948

Li, T., Munir, Q., \& Abd Karim, M. R. (2017). Nonlinear relationship between CEO power and capital structure: Evidence from China's listed SMEs. International Review of Economics $\mathcal{E}$ Finance, 47, 1-21. doi: https://doi.org/10.1016/j.iref.2016.09.005

MacKay, P., \& Phillips, G. M. (2005). How does industry affect firm financial structure? Review of Financial Studies, 18(4), 1433-1466. doi: https://doi.org/10.1093/rfs/hhi032

Masood, O., \& Fry, J. (2012). Risk management and basel-accord-implementation in Pakistan. Journal of Financial Regulation and Compliance, 20(3), 293-306. doi: https://doi.org/10.1108/13581981211237981

Myers, S. C., \& Majluf, N. S. (1984). Corporate financing and investment decisions when firms have information that investors do not have. Journal of Financial Economics, 13(2), 187-221. doi: https://doi.org/10.1016/0304-405X(84)90023-0

Narayan, P. K., \& Phan, D. H. B. (2019). A survey of Islamic banking and finance literature: Issues, challenges and future directions. Pacific-Basin Finance Journal, 53, 484-496. doi: https://doi.org/10.1016/j.pacfin.2017.06.006

Naveed, M., Ramakrishnan, S., Anuar, M. A., \& Mirzaei, M. (2015). Factors affecting speed of adjustment under different economic conditions. Journal of Chinese Economic and Foreign Trade Studies, 8(3), 165-182.

doi: https://doi.org/10.1108/JCEFTS-08-2014-0015

Pellegrina, L. D. (2012). Does capitalization enhance efficient risk undertaking?: A comparison between Islamic and CBs. Accounting Research Journal, 25(3), 185-207. doi: https://doi.org/10.1108/10309611211290167

Rashid, A. (2016). Does risk affect capital structure adjustments? The Journal of Risk Finance, 17(1), 80-92. doi: https://doi.org/10.1108/JRF-06-2015-0060 
Rashid, A., Khaleequzzaman, M., \& Jabeen, S. (2015). Analyzing performance of banks in Pakistan: Conventional versus Islamic banks. Journal of Islamic Business and Management, 5(2), 1-26. doi: https://doi.org/10.12816/0026416

Roodman, D. (2009). How to do xtabond2: An introduction to difference and system GMM in Stata. The Stata Journal, 9(1), 86-136. doi: https://doi.org/10.1177/1536867X0900900106

Salman, A., \& Nawaz, H. (2018). Islamic financial system and conventional banking: A comparison. Arab Economic and Business Journal, 13(2), 155-167. doi: https://doi.org/10.1016/j.aebj.2018.09.003

Schandlbauer, A. (2017). How do financial institutions react to a tax increase? Journal of Financial Intermediation, 30, 86-106. doi: https://doi.org/10.1016/j.jfi.2016.08.002

Simerly, R. L., \& Li, M. (2000). Environmental dynamism, capital structure and performance: A theoretical integration and an empirical test. Strategic Management Journal, 21(1), 31-49. doi: https://doi.org/10.1002/(SICI)1097-0266(200001)21:1<31::AIDSMJ76>3.0.CO;2-T

State Bank of Pakistan (SBP). (2019). Islamic Banking Bulletin: April-June 2019. Karachi, Pakistan: State Bank of Pakistan. Retrieved from https://bit.ly/3bwymok

Thumrongvit, P., Kim, Y., \& Pyun, C. S. (2013). Linking the missing market: The effect of bond markets on economic growth. International Review of Economics $\mathcal{F}$ Finance, 27, 529-541. doi: https://doi.org/10.1016/j.iref.2013.01.008 


\section{APPENDIX}

\section{Conceptualization of Independent and Dependent Variables}

\begin{tabular}{|c|c|c|c|}
\hline Variables & Symbol & Formulation & Existing Literature \\
\hline \multicolumn{4}{|l|}{ Dependent Variable } \\
\hline Total Leverage Ratio & TLEV & Total Debt/ Total Asset & $\begin{array}{l}\text { (Gropp \& Heider, 2010; } \\
\text { Laux \& Rauter, 2017) }\end{array}$ \\
\hline \multicolumn{4}{|l|}{ Explanatory Variables } \\
\hline P & SIZE & $\begin{array}{l}\text { A. Firm Level } \\
\text { Logarithm Total Asset (Book value) }\end{array}$ & $\begin{array}{l}\text { (Berg \& Gider, 2017; } \\
\text { Gropp \& Heider, 2010) }\end{array}$ \\
\hline Profitability (ROA) & PROF & Net income scaled by total assets & $\begin{array}{l}\text { (Berg \& Gider, 2017; } \\
\text { Gropp \& Heider, 2010) }\end{array}$ \\
\hline $\begin{array}{l}\text { Asset Structure } \\
\text { (Tangibility) }\end{array}$ & TANG & Ratio of Fixed Assets to Total Assets & (Berg \& Gider, 2017) \\
\hline $\begin{array}{l}\text { Growth Opportunity } \\
\text { (Asset Growth) }\end{array}$ & GROW & $\begin{array}{l}\text { Annual Percentage Change in Total } \\
\text { Assets (Yt-Yt-1 }) / Y t-1 * 100\end{array}$ & (Berg \& Gider, 2017) \\
\hline Tax (NDTS) & NDTS & Annual Depreciation to Total Assets & (Schandlbauer, 2017) \\
\hline Dividend & DIV & $\begin{array}{l}\text { Dummy variable: } 1 \text { if firm issue cash } \\
\text { or non-cash dividend otherwise } 0 \\
\text { B. Sector Level }\end{array}$ & $\begin{array}{l}\text { (Kayo \& Kimura, 2011; } \\
\text { Naveed et al., 2015) }\end{array}$ \\
\hline Munificence & MUN & $\begin{array}{l}\text { (Taking the ratio of regression slope } \\
\text { coefficient to the mean value of sales) }\end{array}$ & (Berg \& Gider, 2017) \\
\hline Dynamism & DYN & $\begin{array}{l}\text { Standard error of munificence re- } \\
\text { gression slope coefficient divided by } \\
\text { mean value of sales }\end{array}$ & $\begin{array}{l}\text { (Kayo \& Kimura, 2011; } \\
\text { Naveed et al., 2015) }\end{array}$ \\
\hline Concentration & HHI & $\begin{array}{l}\text { Herfindahl-Hirschman index: Sum } \\
\text { of squares of market shares of firms } \\
\text { within sectors }\end{array}$ & $\begin{array}{l}\text { (Kayo \& Kimura, 2011; } \\
\text { MacKay \& Phillips, } \\
\text { 2005) }\end{array}$ \\
\hline GDP Growth & GDP & $\begin{array}{l}\text { Macro-Economic Level } \\
\text { annual percentage change of gross do- } \\
\text { mestic product }\end{array}$ & $\begin{array}{l}\text { (Berg \& Gider, 2017; } \\
\text { Gropp \& Heider, 2010) }\end{array}$ \\
\hline Inflation & INFL & $\begin{array}{l}\text { annual percentage change in average } \\
\text { consumer price index }\end{array}$ & $\begin{array}{l}\text { (Berg \& Gider, 2017; } \\
\text { Gropp \& Heider, 2010) }\end{array}$ \\
\hline Stock Market Development & SMKT & $\begin{array}{l}\text { stock market capitalization as a share } \\
\text { of GDP }\end{array}$ & $\begin{array}{l}\text { (Chipeta \& Deressa, } \\
\text { 2016; Naveed et al., } \\
\text { 2015) }\end{array}$ \\
\hline Bond Market Development & BMKT & $\begin{array}{l}\text { Bond market capitalization as a share } \\
\text { of GDP }\end{array}$ & $\begin{array}{l}\text { (Chipeta \& Deressa, } \\
\text { 2016; Naveed et al., } \\
\text { 2015) }\end{array}$ \\
\hline
\end{tabular}

